\title{
Archival research: unravelling space/time/matter entanglements and fragments
}

\author{
Maria Tamboukou \\ University of East London, UK
}

\begin{abstract}
In recent years, archival research in the social sciences is emerging as a vibrant field of qualitative research, with contributions from a range of disciplinary fields, epistemological standpoints, theoretical insights and methodological approaches. In this article, I explore archival research strategies in life-history research, drawing on my experience of working at the Harry Ransom Humanities Research Centre, University of Texas at Austin, reading the letters of Dora Carrington (1893-1932), an English painter, who lived and worked in the peripheries of the Bloomsbury group. The archive in my analysis is theorized as a spatial and discursive apparatus of experimentation, whose configuration has an impact on the type of data and the kind of knowledges that will derive from it. Drawing on neo-materialist approaches in feminist science studies, what I suggest is that the researcher's questions, interpretations, theoretical insights and analytical tropes emerge as intra-actions between space/time/matter relations and forces within the archive.
\end{abstract}

\section{Keywords}

archives, Barad, diffractions, intra-actions, letters, rhythms, space/time

In recent years, archival research in the social sciences is emerging as a vibrant field of qualitative research, with an interesting body of literature gradually amassing around it. ${ }^{1}$ Here, Liz Stanley's work with Olive Schreiner's epistolary archive ${ }^{2}$ has been pathbreaking not only in showing the wide range of social issues that researchers can explore through archival research, but also in shaping new methodological approaches in the study of 'documents of life' (Plummer, 2001). In a special issue on 'Qualitative Archives and Biographical Research methods', Miguel Valles et al. (2011) have presented a rich range of articles dealing with not just questions around archiving but also reuse and reanalysis of existing qualitative data, a field which is also on the rise, given the digital transpositions that have been radically changing the nature of the archive, as well 
as the approaches to archival research. While mapping the field of archives and lifehistory research, the articles of this volume have not only highlighted achievements and strengths but have also pointed to areas that need to be further explored and theorized within the horizon of an overall archival sensibility.

In this article, I attempt to make a contribution to such theoretical and methodological questions and debates by looking back into my experience of doing archival research at the Harry Ransom Humanities Research Centre (HRC), University of Texas at Austin, reading the letters of Dora Carrington (1893-1932), an English painter, who lived and worked in the peripheries of the Bloomsbury group. In doing this, I explore questions and issues of material and discursive entanglements within the archive. Drawing on Karen Barad's (2007) neo-materialist approaches in feminist science studies, what I suggest is that the researcher's questions, interpretations, theoretical insights and analytical tropes emerge as intra-actions between space/time/matter relations and forces within the archive.

\section{In search of Carrington}

My interest in Carrington was not accidental. While working for a feminist genealogy of the constitution of the female self in art, Carrington emerged as a particularly intriguing figure, since she was within the fin de siècle milieu of my genealogical explorations. While doing background research about her life, I first read her only published biography, Carrington, A Life (Gerzina-Holbrook, 1989). In reading this biography, I was deeply impressed by the richness of Carrington's letters, which I was keen to find more about. David Garnett's (1975) edited collection of Carrington's letters and diaries was the first step here. This is indeed a rich anthology, but like all edited collections, it operates with certain inclusions and exclusions.

This is how I was eventually driven to the archives and got immersed in the dusty world of manuscripts. Between January and June 2004, I worked on a weekly basis at the manuscript section of the British Library in London reading Carrington's unpublished diary, D. Partridge: Her Book and the 10 files of her correspondence with Lytton Strachey. ${ }^{3}$ Apart from the rich data I collected there, what really struck me with the manuscripts were the artistic drawings of the letters and the delightful entanglements of images and words. I had seen Carrington's epistolary drawings in Garnett's volume, but I had not realized the artful way that words and images were interlaced in the body of her original letters. This was one of the many pleasures of working with the manuscripts, which later became a theme in my analysis: the importance of epistolary art in the constitution of the self and the entanglements of human relations (see Tamboukou, 2010).

Studying Carrington's letters to Strachey made me want to read more, and this is how I traced the bulk of her remaining extant correspondence at the $\mathrm{HRC}$ at the University of Texas at Austin. A small grant from the Art and Humanities Research Council (AHRC) gave me the opportunity to visit this amazing research centre, where I worked intensely between June and July 2004. Carrington's letters are kept in 10 files of outgoing correspondence between 1915 and 1931 and 17 files of incoming correspondence from 1912 to 1932 . What I was also able to read in Austin was the Brenan-Carrington correspondence, 434 letters to Brenan (1919-1932) and 465 letters from Brenan (1919-1932). 
Finally, in the HRC collection, I was able to locate the only letter I have ever read from Carrington to her husband Ralph Partridge, something I had not expected to find, since according to Garnett (1975), 'her letters to Ralph Partridge were not preserved' (p. 15).

This is certainly a big and interesting gap in Carrington's correspondence, and I really feel very satisfied even with the single letter I was able to detect. ${ }^{4}$ It has to be noted here that the content of this letter is not significant - Partridge was away for a sports event and Carrington was writing news from their home at Tidmarsh. However, as a single isolated document from the archives, this letter has opened up an intriguing theme in my analytical tropes: the significance of absence, letters that were lost or destroyed. As Carolyn Steedman (2001) has poetically put it, 'you find nothing in the Archive but stories caught half way through: the middle of things: discontinuities' ( $p$. 45). The letter that was preserved thus became a constant reminder that my archival documents are full of fragments and discontinuities. In this light, Carrington's extant letters were read with the letters that were lost or destroyed in mind; in the same way that we interpret voices, we should perhaps start interpreting silences or somehow include them in our analysis. 'Archives are neither faithful to reality nor totally representative of it; but they play their part in this reality, offering differences and alternatives to other possible statements', Arlette Farge (1993: 5) has pithily remarked.

In making these references to the lost or destroyed letters, what I am trying to do is to underscore the inevitable partiality of life-history documents and auto/biographical narratives. As a narrative researcher in the archive, I have also created my own rhythms, made selections and decided on inclusions and exclusions. Instead of obscuring the interpretational strategies of my research, I will rather expose them, inviting my readers to join the overall process of deconstructing archival auto/biographical sources and narratives, a move that I will now turn to.

\section{Entanglements of matter and meaning}

Steedman (2001) has eloquently written about the historian's loneliness particularly experienced in the archive: 'The Archive allowed the imagining of a particular and modern form of loneliness' (p. 72). She has further suggested however, that 'the Historian goes to the Archive to be at home as well as to be alone' (p. 72). I want to reflect on loneliness and on these strange connections between loneliness, the archive and the feeling of being at home drawing on my experience at the HRC archives in Austin, Texas.

I arrived in Austin on a very hot June afternoon in 2004, and after leaving my luggage in a colonial style bed and breakfast, made my way to the HRC, which was nearby. Everything seemed strange: summer in Texas but in a city that was so different from the usual stereotypes of what Texas means for Europeans: the motto on almost every merchandise in the souvenir shops was 'Keep Austin weird'. There was also an extraordinary research centre housing the bulk of the Bloomsbury articles: 'how on earth had they ever landed there?' I kept wondering.

There was definitely a strange combination of cultural dynamics, ethnicities, spaces and places: a UK-based researcher of Greek origin funded by a British Institution to read the articles of a British painter, which had been sold to a US Institution. It was the perfect combination for disorientation, which was significantly raising the levels of 'the archive 
fever' both in Steedman's (2001) and Derrida's (1998) conceptualization. ${ }^{5}$ In summary, there I was in a terra incognita, having given up my summer holidays: I was alone in the archive but certainly not feeling at home, or so I thought.

As the days started passing by, the initial 'out of place feeling' was gradually receding and a 'home-like' routine was being created: I would work in the archives from 9 a.m. to 5 p.m., immersed in the Bloomsbury atmosphere of Carrington's correspondence; when the archives closed, I would take the bus and dive into a nearby natural swimming pool at the banks of the Colorado river in a Mediterranean mode of what summer should be about. The experience on the bus was interesting on its own since it familiarized me with people I could never talk to as a 'visiting scholar'. In the evening, I would dine downtown at some American rock, jazz or blues bar - Austin prides itself for being the world capital of life music, and there is live music almost everywhere you go. Back in my colonial style bed and breakfast, I would write my field notes for the day. As I was moving in between several real-and-imaginary spaces and places, day after day, my reading of Carrington's letters would focus more and more on the theme of placelessness: an endless striving not just for a studio of her own but also for a place in the world. This search of lost space ${ }^{6}$ eventually became 'a plane of consistency' for the different expressions and forms of Carrington's letters to be charted and held together. It has to be noted here that 'consistency' in Deleuze and Guattari's (1988) analyses should not be understood as a constant reproduction of sameness or as the segmentation of certain structures and forms of analysis; as Deleuze and Guattari (1988: 70) write, 'continuum of intensities, combined emission of particles or signs-particles, conjunction of deterritorialized flows: these are the three factors proper to the plane of consistency'.

In this light, 'a plane of consistency' in my research refers to the consistency of a grid of analysis and writing style through which differences in form, content and expression within Carrington's epistolarity have been assembled, not as oppositions but as rich heterogeneities, narrative forms in becoming. The search of lost space has further emerged as the refrain of my analysis, a kind of a musical repetition that draws circles within the chaos of the correspondence and is soothing both for the researcher and the reader. ${ }^{7}$ This refrain of 'the lost space' has helped me find my way while navigating the rough seas of the archive and has been discursively expressed in the form of a monograph and a series of journal articles (see Tamboukou, 2010, 2011). Carrington's letters and diaries, archival practices, theoretical ideas and methodological strategies, in short matter and meaning, have been entangled in the writing of the research. But how has this happened?

In reflecting on my experience at the $\mathrm{HRC}$ archives at Austin, what I want to argue is that the material conditions of working in the archive are not mere practicalities or technicalities; they are always interrelated with specific methodological decisions and theoretical paths that the researcher is led to follow. This brings me to the question of how the researcher's experience in the archive creates certain conditions of possibility for what will emerge from the archival research: how she will make selections about what to see, note, transcribe or ask to be photocopied. ${ }^{8}$ These questions relate to wider issues of how the researcher can oscillate between pathos and distance, how she can create a transitional space that can accommodate both her involvement and her need for detachment; it is this fort-da movement that will eventually shatter norms and certainties about what can or should be researched, within real-and-imaginary spaces. I will try to tackle this 
problem drawing on Karen Barad's (2007) methodological suggestion of working diffractively, as well as the correlated notion of 'intra-actions', which I will explicate in the next section.

\section{Diffractions and intra-actions}

There is a strong tendency in social sciences research in general and in narrative research in particular, for self-reflexivity. As researchers, we are expected to reflect on our methods and situate ourselves in the research process by thinking about the effects of our methodologies and theories upon the 'research findings'. While positing the epistemological project of 'situated knowledges', Dona Haraway has criticized reflexivity, putting forward 'diffraction' as an alternative tool of meaning making:

Reflexivity has been recommended as a critical practice, but my suspicion is that reflexivity, like reflection, only displaces the same elsewhere, setting up worries about copy and original and the search for the authentic and really real [...] Diffraction is an optical metaphor for the effort to make a difference in the world [...] Diffraction patterns record the history of interaction, interference, reinforcement, difference. Diffraction is about heterogeneous history, not about originals [...] Diffraction is a narrative, graphic, psychological, spiritual and political technology for making consequential meanings. (Haraway, 1997, cited in Barad, 2007: 71)

The optical metaphor of diffraction that Haraway (1992) has proposed as a pattern of mapping 'where the effects of difference appear' (p. 300) has been taken up by Barad (2007) 'as a methodological approach ... of reading insights through one another in attending to and responding to the details and specificities of relations of difference and how they matter' (p. 71). Being a physicist as well as a feminist theorist, Barad is scrutinizing diffraction as an optical phenomenon in not just classical physics but also in quantum physics. As a quantum way of knowing according to Barad (2007), diffraction apparatuses not only 'measure the effects of difference [but] even more profoundly, they highlight, exhibit, and make evident the entangled structure of the changing and contingent ontology of the world, including the ontology of knowing' (p. 73).

Drawing on Niels Bohr's philosophy-physics, ${ }^{9}$ Barad $(2003,2007)$ has further introduced the neologism of 'intra-actions' as a theoretical juxtaposition to the usual notion of interactions. In doing this, she denotes a significant difference: while interactions occur between already-established and separate entities, 'intra-actions' occur as relations between components. Entities - both human and non-human - actually emerge as an effect of these intra-actions, without having stable points or positions, an argument succinctly summarized in the following:

Existence is not an individual affair. Individuals do not preexist their interactions; rather individuals emerge through and as part of their entangled intra-relating. Which is not to say that emergence happens once and for all, as an event or as a process that takes place according to some external measures of space and of time, but rather that time and space, like matter and meaning, come into existence, are iteratively reconfigured through each intra-action, thereby 
making it impossible to differentiate between creation and renewal, beginning and returning, continuity and discontinuity, here and there, past and future. (Barad, 2007: ix)

Making connections between intra-actions in scientific experiments in the field of quantum physics and narrative research in the social sciences, what I want to argue here is that 'the researcher', 'the letters in the archive' and the 'research strategies of narrative analysis' cannot be taken as separate and pre-existing entities that interact in the final stage of the research process, the writing of an article or a monograph in my case. The 'research findings' and, consequently, the research publications around Carrington rather emerged through the multifarious entanglements - both material and discursive - between 'the researcher', 'the research object' and 'the research context'. As a matter of fact, 'the researcher', 'the research object' and 'the research context' are not predefined entities either: they are constituted through entangled intra-actions, and their particular constitution can only hold within the conditions of the research process, the experiment or rather the 'narrative phenomenon' within which they emerge.

In employing the notion of 'narrative phenomenon', I follow here Barad's (2003) reconfiguration of Bohr's thesis that 'things do not have inherently determinate boundaries or properties, and words do not have inherently determinate meanings' (p. 813). It is only through the configuration of a particular 'phenomenon' that things can be bounded and acquired properties and words can take up meaning. As Barad (2003) explains, 'Bohr's epistemological framework rejected both the transparency of measurement as well as the transparency of language' (p. 813), and in this light, the primary epistemological unit for Bohr was 'the phenomenon', marked by the inseparability of 'the observed object' and 'agencies of observation' (p. 814). While challenging the separation between subject and object and knower and known, Bohr's philosophy-physics maintained and defended the possibility of objective knowledge within the configurations of a particular phenomenon. What Barad's proposition has added to Bohr's thesis, however, is that phenomena are not only epistemological units, but milieus within which things can be measured and meaning can be enacted; phenomena in Barad's (2003) theorization are ontological units, constitutive of reality:

Reality is not composed of things-in-themselves or things-behind-phenomena but 'things'in-phenomena. The world is intra-activity in its differential mattering. It is through specific intra-actions that a differential sense of being is enacted in the ongoing ebb and flow of agency. (p. 817)

It is precisely my entanglement in this intra-active world of differential mattering that I have found fascinating about working in the HRC archive with Carrington's letters, diaries and drawings. In recognizing that the complex matter/space/time relations of my research experience at Austin created a specific 'narrative phenomenon', wherein material conditions and discourses were intertwined, I agree with Barad's argument that the research apparatus - the archive in my case - is inevitably entangled with the phenomenon. Drawing on Bohr's epistemological framework, Barad (2007) has particularly problematized the nature and meaning of 'the apparatus' in scientific research: 
According to Bohr apparatuses are macroscopic material arrangements through which particular concepts are given definition, to the exclusion of others and through which particular phenomena with particular determinate physical properties are produced ... the apparatus plays a much more active and intimate role in experimental practices than classical physics recognizes. Apparatuses are not passive observing instruments; on the contrary they are productive of (and part of) phenomena. (p. 142)

The neutral role of the apparatus has thus been seriously challenged in quantum physics, but this challenge is clearly not restricted within laboratory experiments. In drawing analogies between the apparatus in scientific research and the archive as an apparatus in narrative research, what I want to emphasize here is that the specific material, spatial and discursive conditions of my archival research at the HRC in Austin, Texas, had a significant impact on the conduct and outcome of the research. In the same way that 'apparatuses are not passive observing instruments', archives are not neutral sites within which researchers 'objectively' read, take notes and accumulate data. 'Apparatuses are openended practices' according to Barad (2003: 816), and so are archives. The archive is a dynamic spatial and discursive milieu forcefully acting upon the research process, the analytics of the research, the 'research findings' and the researcher herself; in short, it both produces and becomes part of the specific 'narrative phenomenon' under scrutiny. It is through the entanglement of such forceful 'intra-actions' that 'entities' like research reports, articles or books eventually emerge as effects of a research experiment within the particular conditions of the 'narrative phenomenon'.

But what are the conditions of possibility for meaning to be enacted and particular types of knowledge to emerge within the material and discursive entanglements of the phenomenon? This is where Barad's (2007) notion of 'agential realism', a recognition of matter's dynamism becomes crucially important:

The dynamics of intra-activity entail matter as an active 'agent' in its ongoing materialization. Or rather, matter is a dynamic intra-active becoming that is implicated and enfolded in its iterative becoming. Matter(ing) is a dynamic articulation/configuration of the world. (p. 151)

As already noted above, matter does not refer to pre-existing entities with stabilized substances and calculable properties and attitudes, rather it refers to phenomena and their intra-active entanglements. It is this dynamic process of materialization that Barad (2007) conceives as agential or rather as 'a congealing of agency' (p. 151). 'Intra-action' is actually a notion that according to Barad (2003) 'constitutes a reworking of the traditional notion of causality' (p. 815). Why is that? Causality as a relation presupposes preexisting entities that act upon each other being constituted as causes and/or effects. In the absence of separability among the components of the phenomena, intra-actions between them become agentic forces through which the components become determinate within the conditions of the phenomenon they are part of. As Barad (2003) succinctly argues, 'it is through specific agential intra-actions that the boundaries and properties of the "components" of phenomena become determinate and that particular embodied concepts become meaningful' (p. 815). This is how the conditions of possibility exist for meaning to be enacted and knowledge to emerge within the phenomenon. 
Barad's discussion emphasizes the fact that agential realism as a theoretical proposition goes beyond the understanding of scientific practices: 'agential realism offers an understanding of the nature of material-discursive practices, such as those very practices through which different distinctions get drawn, including those between the "social" and the "scientific" (p. 815). Through intra-actions between fragments of letters and correspondences, the fluid conditions of the archive and the researcher's labile position within its milieu, narrative sense is enacted and knowledge emerges in the form of a report, an article or a monograph. This form of narrative knowledge, however, is not an effect of a linear causal relation between 'the life-documents' and 'the archive', 'the research hypothesis' and 'the analysis', 'the observer' and 'the observed' or 'the knower' and the 'known'. What can be known and by whom is an effect of specific intra-actions, within the conditions of the phenomenon. Narrative sense and the particular types of knowledge that derive from it need to be charted within the conditions of the phenomenon or the network of phenomena within which they are constituted: this, I argue, is a crucial task for the narrative researcher.

In thus drawing on Barad's proposition of 'agential realism' and the correlated notion of 'intra-activity', what I have argued is that the material/spatial conditions of my research at the $\mathrm{HRC}$ archives cannot be disentangled from the directions, interpretations and thematic orientations of my analysis and theorization. My experience actually affirms an important corollary in Barad's (2003) proposition: '[since] the primary ontological units are not things but phenomena ... the primary semantic units are not words but material-discursive practices through which boundaries are constituted' (p. 818). In this light, my bodily experiences, emotions, ideas, theoretical preconceptions, initial methodological strategies, previous archival and literature research as well as practical concerns of space/time limitations and financial constraints were dynamically enfolded within the cultural spaces and natural places of Austin. Farge (1993) has discussed the importance of visceral connections with the archives, particularly highlighting the importance of emotions in facilitating access to meaning about the social worlds and relations inscribed in the documents under scrutiny:

For emotion is not fusion between oneself and the archives or the annihilation of all capacity to think in concrete terms, but rather the development of a reciprocity with the object, by which access is given to meaning. (p. 4)

What the Baradian approach adds to Farge's (1989) influential theorization of the 'taste of the archive' is that we are not dealing with relations of reciprocity between separate entities; rather the 'research findings' emerge through and as part of their entangled intrarelating with material and discursive practices. Research is thus conceived as an ongoing process of folding, unfolding and refolding that is still going on as I am writing this article.

In taking up the notion of 'the fold' to chart material practices within specific spatial configurations, I draw here on a Leibnizian concept that is central in both Foucault's and Deleuze's philosophies. Deleuze (1993) has used the concept of the fold to trace connections between space and bodies: the world folds into the self in different speeds and on a variety of levels and intensities affecting the ways we live, relate to other bodies and 
make sense of our worldliness. At the same time, however, we keep folding out into the world, argued Foucault (1988) in his later work, acting upon received knowledges, discourses and practices, and thus moulding ourselves as subjects through the deployment of technologies of the self. Elspeth Probyn (1993) has particularly pointed to the crucial concept of the fold in both Foucault's and Deleuze's analyses, foregrounding the very constitution of subjectivity as an incessant process of folding and unfolding: 'The act of pleating or folding ("la pliure") is thus the doubling-up, the refolding, the bending-ontoitself of the line of the outside in order to constitute the inside/outside - the modes of the self' (p. 129). As I have argued elsewhere, letters and diaries should be conceived as 'modes of the self', narrative technologies as I have called them of how women have been constituted as subjects within a continuum of foldings and unfoldings (Tamboukou, 2010).

Barad (2007) has actually pointed to the importance of Foucauldian analytics in human sciences research and has made connections between Foucault's conceptualization of discursive practices with Bohr's account of apparatuses, 'the role they play in the material production of bodies and meanings' (p. 147). Here again, however, Barad has shown the limits of Foucault's theorization in claiming that material practices merely support or sustain discourses, thus erasing the dynamism of matter itself. 'Bohr's point entails a much more intimate relationship between concepts and materiality, matter and meaning', Barad (2007: 147) notes, although anthropocentrism remains a common limitation of both Foucault and Bohr's account.

As an entanglement of spatial and discursive practices, the experience of doing archival work at the HRC at Austin was intra-actively related to the themes, codes and analytical directions of my research with Carrington's letters, drawings, diaries and paintings. The actual process of working in the archives from 9:00 a.m. to 5:00 p.m., day after day, created rhythms and material conditions through which some themes and ideas became central and others remained in the peripheries of my research interest and attention. These ideas and themes emerging for the daily work at the archives became axes along which the research was structured, while material conditions were themselves modified by the orientation of the research: letters read at the end of the day would be revisited the following morning and repetition would enter the archival rhythm as a necessary move to make up for the effects of tiredness upon the research. As Barad (2007) has pointed out, 'discursive practices and material phenomena do not stand in a relationship of externality to each other; rather the material and the discursive are mutually implicated in the dynamics of intra-activity' (p. 152, emphasis in the original).

What I have thus attempted to do in exposing the material conditions and discursive practices of my archival work at Austin is to present it as a 'narrative phenomenon' marked by the dynamism of agential intra-actions through which local separabilities are enacted between 'the knower' and the known', creating conditions of possibility for meaning and knowledge to emerge. It was within the boundaries and limitations of the specific 'narrative phenomenon' that certain letters were selected, themes were created, figures and characters emerged, questions were raised and theoretical frameworks were used to support the analysis and discussion. This cartography of intra-actions was further transferred in the writing of the research: in opening up the black box of the archive, I have not presented Carrington's letters, drawings and diaries as 'evidence of experience' 
(Scott, 1991); I consider them as partial truths, fragments that shed light on some moments of being while obscuring and shadowing others. I do not suggest that there are no causal links in my rendition of Carrington's life and art; these are not linear causalities however: these are unproblematic connections between what she wrote, what she created and what she thought.

\section{Archival interventions: the researcher's cut}

In the previous section, I have discussed Barad's notion of 'intra-actions' as entanglements of relations and spacetimematter phenomena through which individuals and entities emerge without acquiring definitive properties beyond the phenomena in which they are immersed; as simply put by Niels Bohr's philosophy-physics that Barad (2007) has followed, 'we are part of that nature that we seek to understand' (p. 26). But what are the implications of such an approach in understanding entanglements in the researchers' archival strategies?

As I have already noted, while being part of 'the narrative phenomenon' she is trying to understand, the researcher actively intervenes in delimiting its boundaries. The 'researcher's cut' is thus an agentic intervention shaping the form of the research that will emerge as a report, an article or a book. In employing the notion of 'the researcher's cut' to denote relations of exteriority between the researcher and the research object within a specific narrative phenomenon, I have drawn on Barad's theoretical proposition of 'agential realism' - the dynamism of matter in (re)configuring the world. It is within the framework of 'agential realism' that Barad (2007) has coined the notion of 'agential cut':

What the agential cut does provide is a contingent resolution of the ontological inseparability within the phenomenon and hence the conditions for objective description: that is it enables an unambiguous account of marks on bodies, but only within the particular phenomenon. (p. 348)

In Barad's conceptual vocabulary then, the 'agential cut' is a material-discursive intervention in the phenomenon under investigation, not necessarily attached to a subject - as is clearly the case with 'the researcher's cut'. Through this intervention, a local separability is enacted among the interdependent components of the phenomenon under scrutiny. Notwithstanding its contingent nature, this tentative relation of exteriority within the phenomenon creates conditions of possibility for meaning and knowledge to emerge.

Having identified a subject-centred inflection in the way 'the researcher's cut' is configured in my analysis, I want to map this intervention by focusing on what, borrowing from Heidegger's vocabulary, I will call the forestructure of my archival understanding. The choice of a Heideggerian grid is not accidental. Over the many years that I have been working in archives, I have always felt that I have been in a workshop, and while I have never used a hammer for my archival work, I have nevertheless used conceptual tools that were available and 'ready-to-hand' (Heidegger, 2003: 191). In this light, I honestly feel that my emergence as a researcher has been an existential experience of being-in-thearchive. This has always been a strange experience, since the workshop of a sociologist should be the social world, not the archive. However, because of this uneasiness, the uncanny feeling that I do not belong in the archive, entangled with the desire to be there, 
has created the right amount of Heideggerian concern that has made me problematize and question my practices and my tools. As I have written at length (Tamboukou, 2010), archival work is always, already an interpretation and its conditions of possibility are not only historically, politically and culturally but also materially bound. Within the Heideggerian (2003: 191) forestructure of understanding then, interpretation unfolds along three axes: forehaving, foresight and foreconception; it is grounded in something we have, we see and we grasp in advance. My situated perspective as a feminist researcher, who has lived and been educated in two European countries and has chosen to move in search of 'personal space', in short, my autobiographical forehaving was clearly entangled with my particular interest in identifying spatial practices in the archival documents I was reading. This spatial focus was also embedded in my foresight through the theoretical frameworks I have been working with since the years of my doctoral studies, namely, feminist genealogies and narratives of space (Tamboukou, 2003, 2010). However, my foresight as a feminist sociologist was also significantly coloured by an intense uneasiness with Carrington's life choices and particularly the fact that she died feeling profoundly dissatisfied with her work as a painter. ${ }^{10}$ How was it possible, I was wondering, for a talented middle-class woman, prize-winning student at the Slade and a member of the Bloomsbury group - albeit in its peripheries - not to realize her creativity as an artist? The sociological theories of my foreconception, around intersections of class, gender and culture, did not seem adequate to address this riddle.

However, while I was tightly entangled in the spacetimematter conditions of the archival research at Austin, some eruptions occurred. As I was trying to orient myself in the unfamiliar places of Austin and reimagine Bloomsbury in the archival space of an extraordinary American research centre, in short, my own search of lost space eventually became 'a plane of consistency' for understanding Carrington's and indeed other women artists' lives and social worlds. I was, after all, in a position to have a sociological understanding, to see through Carrington's letters what critical geographers have so persuasively argued: the spatial and the social are inextricably intertwined and mutually constituted (see Massey, 2005). After all these adventures, the mystery was cracked: Carrington was not a hysteric privileged middle-class woman, an image that implicitly emerges from Garnett's (1975) collection of her diaries and letters, but a placeless female subject. This insight of placelessness has actually led to an important theme in my overall analysis: the need to reconsider what I have called 'the private hypothesis', the argument of the centrality of the private sphere in understanding women's oppression. What I have argued is that alongside the private/public well-rehearsed division, ${ }^{11}$ we need to examine a grey area in the development of the female self in modernity: relations between the private and privacy, as well as the unbearable heaviness of being public (see Tamboukou, 2010).

Farge (1993) has suggested that 'the archive may be a rejection of the meaning we seek to attribute in advance to events' (p. 5), a shift away from our habitual ways of reasoning and understanding. She has actually used the metaphors of explosion and eruption to configure the archive:

I also like to think of the archives as an eruption; because eruption suggests an attack, an incursion, or a sudden and unexpected entry or invasion; for it is in this way that the archives come into their own. (Farge, 1993: 5) 
But how do eruptions occur? What are their conditions of possibility? Through Barad's framework, I could see how the material conditions of my displacement entangled with my reading of Carrington's letters as well as the enjoyment of viewing her paintings and epistolary drawings were active intervention that created a distance, 'a local separability' between the letters and the researcher, but also mobilized 'lines of flight' 12 from the researcher's foresight and foreconception. It was through this relation of exteriority within 'the narrative phenomenon' that specific analytical themes emerged, which eventually shaped the form and directions of my archival research strategies, and consequently my findings and my theorization.

Clearly, the analysis could always include more letters and drawings as 'marks left on bodies' that could enrich the complexity of Carrington's always-ephemeral constitution as a subject. The particular letters I have chosen to focus on as well as the themes that I have further analysed and discussed are effects of my entanglement within the material and discursive conditions of the narrative phenomenon within which my research was inevitably bounded. As Barad (2007) explains, 'scientific practices do not reveal what is already there: rather what is 'disclosed' is the effect of the intra-active engagements of our participation with/in and as part of the world's differential becoming' (p. 361).

Entangled as we are within phenomena either as subjects or objects of the research, the possibility exists of taking up space and (re)configuring practices through which we can make sense of what is going on, intervene in the procedures and phenomena of our entanglement, and therefore, take responsibility for how we mark our position within the phenomena we are trying to understand, analyze and change - and which we are part of. As Barad (2007) has aptly put it, 'There is no absolute inside or absolute outside. There is only exteriority within, that is agential separability' (p. 377).

Seen in this light and from an always inside/outside position, my archival strategies with Carrington's letters have been theorized as a multitude of entangled phenomena through which I have made choices amidst the grey documents of the archive. In the analytical line of agential interventions as explicated above, my archival strategies have thus been conceived as 'the researcher's cut', never the consequence of a linear and closed causality of the research hypothesis, questions and theoretical insights that I initially brought in the archive, although the latter did play a part in situating myself within the research context in the first place.

Having mapped the archive as a spatial and discursive apparatus of experimentation and knowledge production, what I want to do now is to present an exemplar of the research effects of the Baradian approach. In doing this, I will discuss an analytical trope, through which space emerged as a crucial theme of my understanding: the visuality of Carrington's life documents.

\section{Visual technologies}

Yesterday I thought of Spain. It was just a year ago today we started for Yegen. Do you know I think there are very few hours that I cannot remember every detail of at Yegen [...] You know my life is entirely visual and no place ever gave me such exquisite happiness as last winter with you. (Garnett, 1975: 309) 
In the extract above, from a letter to Brenan written in December 1924, Carrington's epistolary discourse brings together two interrelated themes that became crucial in my archival research strategies: spatiality and visuality. In the previous section, I have looked into the importance of the spatial experience of archival research. What I want to discuss here is how the spatial and the visual became methodological trails that I followed while working in the archive as well as tropes that guided the analysis of the life documents that my archival research had accumulated.

As already noted in the first section, Carrington's letters are kept in 27 files of correspondence between 1912 and 1932. In addition, there were almost 1000 letters in the Brenan-Carrington correspondence spanning the period between 1919 and 1932. As I immersed myself in this immense bulk of correspondence, a rhythm was gradually established that was both spatial and visual. I will try to freeze some moments of this archival rhythm by focusing on Carrington's letters, drawings and painting that revolve around the Yegen mountains:

I must tell you first of the most magnificent walk we had from Orgeva here [...] walking on the spine of a high range of mountains in view of the sea the whole time. And do you know I SAW the mountains of AFRICA [...] We walked through the most marvellous cork forests. The country was extremely varied, sometimes bleak, and arid and sometimes covered with wild herbs and bushes [...] The country after lunch became far wilder, ravines and great rocks with the sea behind us, the sun casting fascinating shadows on the rocks and making the mountains, when it set, a ravishing Pussin pinkish brown [...] The landscape looked astonishing. The moon shone in a sky of stars, the air was quite warm and the mountains became more and more fantastic every moment. Doré, or Blake could hardly have conceived anything more frenzied. (Garnett, 1975: 266)

In this extract from a letter written to Strachey on 23 December 1923, Carrington offers a colourful narrative image of the Yegen mountains, which unfolds in the eyes of the letter-writer and her reader in the process of a whole day. The beauty of the Yegen mountains left a lasting impression upon Carrington, which was transposed in what I think is one of her best paintings: the Yegen Landscape. ${ }^{13}$ Carrington painted it from memory, as an assemblage of drawings and 'remembered images' diffracted by poetic imagination. As a pictorial mode of retaining the past and enacting memory and imagination, the Yegen Landscape is an almost surreal painting depicting a series of rounded mountains while in the background, the sea separating Spain from the Moors emerges. Apart from unleashing Carrington's creative forces, the painting carried and transmitted signs of existential happiness, lyrically expressed in the many beautiful letters that Carrington wrote about it:

I have just painted for two hours without stopping. I am working on the landscape you liked. The round mountains [...] I am trying a new plan, an entire underpainting in brilliant colours, over which I shall glaze green and more transparent colours. ${ }^{14}$

As her reference to 'a new plan' indicates, Carrington tried hard to realize this painting, not only because she was looking for the right composition or technique but also 
because life and her care for others would always intervene and disrupt her: 'The Yegen landscape has been held up again by Lytton falling ill', ${ }^{15}$ she was writing to Brenan in March 1924, while later in July she was writing, 'I long to start my painting again. It is not in people and relations one finds happiness [...] but in one's work. My head is full of ideas, I feel I may paint all the better'. ${ }^{16}$ As a matter of fact, she did paint better - the painting was eventually completed and was highly appreciated by art critics:

Carrington's painting of the ruthlessly bare sunset mountains, coloured and marked like the fruit of the prickly pear, has the imaginative intensity of Sasseta's Flaggelation of St Anthony [...] So dominant is the sensation of the mountains [...] the pimply volcanic irruptions and the primordial looking century plants it comes as some surprise to see the tiny almond trees, and the road carved into the hillside with its four muleback riders. (Hill, 2000: 87)

In this light, Carrington's letter to Brenan about Yegen became in my reading a unit within the unity of what I called 'travel letters' and this unity also became a component of a wider assemblage of her correspondence, which I configured as space/memory letters. In conceptualizing Carrington's letters as 'units within a unity' (Altman, 1982: 167), what I tried to do was to sustain my attention to the uniqueness of each letter while mapping its connections with a range of letters recounting her travels and remembering blissful moments of 'other spaces' far away from home. As Edward Casey (2000) has pithily noted, 'concrete places retain the past in a way that can be reanimated by our remembering them' (p. xi). However, apart from merely being containers of the past, places and spaces are vibrant and dynamic: they release forces that enact memory and imagination, and in so doing, they reconstruct the past as well as our experiences of both past and present moments of being.

The visuality of Carrington's letters and diaries was indeed a unique element, as well as a recurrent theme of her auto/biographical archive, 'the plane of consistency' that I created to direct my archival research strategies. In reading Carrington's letters and diaries, I followed the range of visual technologies that she deployed to express her love for space in her writings, drawings and paintings. I thus charted a colourful diagram of textual and visual images that carried traces of Carrington's 'lines of flight' through real and imagined spaces, what I called 'epistolary topographies of the self' (Tamboukou, 2011). It was through the visuality of these documents and their intra-actions with her paintings that Carrington's archival narrative emerged and developed, first guiding my research and later shaping my analysis.

In thus following textual and visual traces of Carrington's spatiality, what I have argued is that while we will never be able to 'find the truth about Carrington', we can have glimpses in the web of material conditions and discursive practices constitutive of the world she was entangled with. As Barad (2007) has noted, 'the boundaries that are enacted are not abstract delineations but specific material demarcations not in space but of space' (p. 181, my emphasis). In this light, it was the materiality of Carrington's letters, the diverse archival spaces as well as the spatiality of the researcher that enacted and reconfigured research strategies with her 'documents of life' (Plummer, 2001) as encountered in the archive. 


\section{Whose archive? Diffractions within phenomena}

In looking back into my archival research strategies with Carrington's letters in this article, I have considered entanglements between spaces, documents and subjects, both real and textual. What I have argued is that archival research is fragmented through and through: there is always something missing, because not everything found a place in an archive, because of serendipity, because of intentional selections and deselections as well as because of specific rules of taxonomy and classification that allow certain documents of life to be preserved and others to become obscure or marginalized. Discontinuous and interrupted as they are, archival documents make connections with the researcher's spatio-temporal rhythms, creating a plane of consistency for specific methodological strategies to be deployed, further selections to be made and certain forms of knowledge, analytical themes and research outputs to emerge. The archive has thus been theorized as a spatial and discursive apparatus of experimentation, whose configuration has an impact on the type of data and the kind of knowledges that will derive from it.

What I have also argued is that while working in the archive, the researcher is always creating an archive of her own, which gradually becomes part of wider fields and bodies of knowledge. It is the researcher's archive, or what I have called 'the researcher's cut', that creates a unity, piecing together archival fragments, theoretical insights, spatio-temporal experiences and material conditions and limitations. This acknowledgement of fragmentation as a dynamic process derives from the thesis of flat ontologies and flat epistemologies or what Barad (2007) has theorized as intraactions and diffractions.

Notwithstanding the recognition that as narrative researchers we are always, already part of the storyworlds that we are trying to understand, what I have finally tried to show in this article is that there are different disciplinary, theoretical, epistemological and material positions that diffractively shape the processes of how we deal with fragmented archival documents but also create conditions of possibility for local separabilities to be enacted within the research process between the knower and the known. In this light, the task of the researcher is to map 'the narrative phenomena' she is working with, open up the black box of archival research and ultimately challenge and problematize the unity of the entities that emerge from her research, be they analytical themes, concepts, discourses, stories or subjects.

\section{Funding}

This research was supported by the Art and Humanities Research Council (AHRC) under the research grant B/SG/AN10693/APN17267. At the time of the award AHRC was actually a Research Board (AHRB).

\section{Notes}

1. See among others, Farge (1989), Steedman (2001), Kirsch and Rohan (2008) and Jobs and Lüdtke (2010).

2. For an overview of the Olive Schreiner's archive, see http://www.oliveschreiner.org/. See also Stanley (2011).

3. British Library/Manuscripts/ Add. 62888-62897/ Dora Carrington correspondence with Lytton Strachey; Add. 65159/ Dora Carrington Diary: DC Partridge, Her Book. 
4. HRC/DC Collection/B.3/ F.7 /Partridge Ralph, 1919/Letter from Carrington.

5. I refer here to Steedman's Dust, a lucid analysis of archival work, which also addresses Derrida's famous Archive Fever (1998). See Steedman (2001).

6. There are intertextual connections here of course with the Proustian search of lost time.

7. The refrain is a concept that Deleuze and Guattari discuss in their work, Thousand Plateaus (1988, see in particular, Part II, 310-350).

8. There were certain restrictions of how many photocopies researchers were allowed to have according to the Harry Ransom Humanities Research Centre (HRC) regulations.

9. The Nobel laureate physicist Niels Bohr (1885-1962) was one of the founders of quantum physics and also the most widely accepted interpretation of the quantum theory, which goes by the name of the Copenhagen interpretation. For a detailed discussion of Bohr's philosophy-physics, see Barad (2003, 2007).

10. Carrington committed suicide in 1932, shortly after the untimely death of her beloved friend and lifelong companion, Lytton Strachey. Her dissatisfaction with her paintings is a constant theme of her correspondence. For a full discussion of Carrington's life and art, see Tamboukou (2010).

11. I refer here, of course, to the rich body of feminist literature around the private and the public (see Scott and Keates, 2004).

12. 'Lines of flight' as a concept from Deleuze and Guattari's (1988) philosophy denoting a detachment from social, political and cultural grounds, another way of theorizing resistance.

13. See the Yegen Landscape at: http://paintingdb.com/view/6857/

14. HRC/GB Collection/B.12/F.2/February-March 1924/ Letter from Carrington, 4/3/1924.

15. HRC/GB Collection/B.12/F.2/February-March 1924/ Letter from Carrington, 4/3/1924.

16. HRC/GB Collection/B.12/F.2/July-August 1924/ Letter from Carrington, 4/3/1924.

\section{References}

Altman J (1982) Epistolarity: Approaches to a Form. Columbus, OH: Ohio State University Press.

Barad K (2003) Posthumanist performativity: toward an understanding of how matter comes to matter. Signs 28(3): 801-831.

Barad K (2007) Meeting the Universe Halfway: Quantum Physics and the Entanglement of Matter and Meaning. Durham, NC: Duke University Press.

Casey E (2000) Remembering: A Phenomenological Study (2nd Edition). Bloomington, IN and Indianapolis, IN: Indiana University Press.

Deleuze G (1993) The Fold: Leibniz and the Baroque (trans. T Conley). Minneapolis, MN: University of Minnesota Press.

Deleuze G and Guattari F (1988) A Thousand Plateaus: Capitalism and Schizophrenia (trans. B Massumi). London: The Athlone Press.

Derrida J (1998) Archive Fever (trans. E Prenowitz). Chicago: The University of Chicago Press.

Farge A (1989) Le goût de l'archive. Paris: Gallimard.

Farge A (1993) Fragile Lives (trans. C Shelton). Cambridge: Polity Press.

Foucault M (1988) Technologies of the self, In: Martin L, Gutman H and Hutton P (eds) Technologies of the Self. London: Tavistock, 16-49.

Garnett D (1975) Carrington: Letters and Extracts from Her Diaries. London: Cape. Gerzina-

Holbrook G (1989) Carrington. New York and London: W.W. Norton \& Company.

Haraway D (1992) 'The promises of monsters: a regenerative politics for inappro-priate/d others.' In: Grossberg L, Nelson C and Treichler P (eds) Cultural Studies. New York: Routledge, 295-337.

Haraway D(1997) Modest_Witness@Second_Millennium.FemaleMan_Meets_OncoMouse:Feminism and Technoscience. New York: Routledge. 
Heidegger M (2003) Being and Time (trans. J Macquarrie and E Robinson). Oxford: Blackwell. Hill J (2000) The Art of Dora Carrington. London: The Herbert Press.

Jobs S and Lüdtke A (eds) (2010) Unsettling History: Archiving and Narrating in Historiography. Frankfurt: Campus Verlag.

Kirsch GE and Rohan L (2008) Beyond the Archives: Research as a Lived Process. Carbondale, IL: Southern Illinois University Press.

Massey D (2005) For Space. London: Sage.

Plummer K (2001) Documents of Life 2. London: Sage.

Probyn E (1993) Sexing the Self: Gendered Positions in Cultural Studies. London: Routledge.

Scott JW (1991) The evidence of experience. Critical Inquiry 17(4): 773-797.

Scott JW and Keates D (eds) (2004) Going Public: Feminism and the Shifting Boundaries of the Private Sphere. Urbana, IL and Champaign, IL: University of Illinois Press.

Stanley L (2011) Olive Schreiner, 'A Returned South African', her letters, her essays, her fiction, her politics, her life: the epistolarium revisited. In: Stanley L (ed.) Olive Schreiner \& Company: Schreiner's Letters and 'Drinking In the External World' (Olive Schreiner Letters Project, Working Paper on Letters, Letterness \& Epistolary Networks No. 3). Edinburgh: University of Edinburgh, 19-44. Available at: http://www.oliveschreinerletters.ed.ac.uk/OSandCompany2011PDF.pdf

Steedman C (2001) Dust. Manchester: Manchester University Press.

Tamboukou M (2003) Women, Education and the Self: A Foucauldian Perspective. Basingstoke: Palgrave Macmillan.

Tamboukou M (2010) Visual Lives: Carrington's Letters, Drawings and Paintings (British Sociological Association, Auto/Biography Monograph Series). Nottingham: Russell Press.

Tamboukou M (2011) Rethinking the private hypothesis: epistolary topographies in Carrington's letters. Emotion, Space and Society 4(1): 25-34.

Valles M, Miguel S, Corti L, et al. (2011) Qualitative archives and biographical research methods. An introduction to the FQS special issue (19 paragraphs). Forum Qualitative Sozialforschung/ Forum: Qualitative Social Research 12(3): article 8. Available at: http://nbn-resolving.de/ urn:nbn:de:0114-fqs110381

\section{Archival sources}

Harry Ransom Humanities Research Centre (HRC), the University of Texas at Austin: Dora Carrington (DC) Collection, Gerald Brenan (GB) Collection.

British Library, Manuscripts (BL): Dora Carrington correspondence with Lytton Strachey [Add. 62888-62897], Dora Carrington Diary: DC Partridge, Her Book [Add. 65159]. 